\title{
Left ventricular hypertrophy among black hypertensive patients: focusing on the efficacy of angiotensin converting enzyme inhibitors
}

\author{
Gari Negeri Jaleta', Esayas Kebede Gudina ${ }^{1 *}$ and Wondim Getinet ${ }^{2}$
}

\begin{abstract}
Background: Left ventricular hypertrophy (LVH) is an independent cardiovascular risk factor in patients with essential hypertension. The main objective of this study was to assess the echocardiographic prevalence of left ventricular hypertrophy in patients with hypertension, its risk factors and effect of antihypertensive drugs on its prevalence.

Methods: A hospital based cross sectional study was conducted on 200 hypertensive patients on treatment in southwest Ethiopia. A pretested structured questionnaire was used to collect data from participants and their clinical records. Blood pressure and anthropometric measurements were taken according to recommended standards. Left ventricular mass was measured by transthoracic echocardiography. Associations between categorical variables were assessed using chi-square test and odds ratio with 95\% confidence interval. Logistic regression model was done to identify risks factors of $\mathrm{LVH}$. P values of $<0.05$ were considered as statistically significant.

Results: The mean age, systolic blood pressure, diastolic blood pressure and body mass index were $55.7 \pm$ 11.3 years, $139.2 \pm 7.7 \mathrm{mmHg}, 89.2 \pm 5.7 \mathrm{mmHg}$ and $24.2 \pm 3.4 \mathrm{Kg} / \mathrm{m}^{2}$ respectively. The overall prevalence of $\mathrm{LVH}$ among these study subjects was $52 \%$. Age $\geq 50$ years (OR: $3.49,95 \% \mathrm{Cl} 1.33-9.14, \mathrm{P}=0.011$ ), female gender (OR: 7.69, $95 \% \mathrm{Cl} 3.23-20.0, \mathrm{P}<0.001)$, systolic blood pressure $\geq 140 \mathrm{mmHg}(\mathrm{OR}: 2.85,95 \% \mathrm{Cl} 1.27-6.41, \mathrm{P}=0.011)$, and duration of hypertension (OR: 3.59, 95\% Cl 1.47-8.76, $\mathrm{P}=0.005$ ) were independent predictors of left ventricular hypertrophy. Angiotensin converting enzyme (ACE) inhibitors were the only antihypertensive drugs associated with lower risk of left ventricular hypertrophy (OR: 0.08, 95\% Cl 0.03-0.19, p < 0.001).

Conclusions: Left ventricular hypertrophy was found to be highly prevalent in hypertensive patients in Ethiopia. ACE inhibitors were the only antihypertensive drugs associated with reduced risk of LVH. We thus recommend strategies to early detect and treat hypertension and to timely screen for LVH among patients with hypertension. Multicenter prospective studies in Africa settings would be ideal to identify the best antihypertensive agents in black Africans.
\end{abstract}

Keywords: Hypertension, Left ventricular hypertrophy, Cardiovascular disease, Angiotensin converting enzyme inhibitors, Ethiopia, Africa

\section{Background}

Cardiovascular disease (CVD) is the leading cause of death globally resulting in about $30 \%$ of deaths annually. About half of CVD related deaths are attributable to hypertension, a disease strongly associated with overall cardiovascular risk [1].

Long standing hypertension results in left ventricular hypertrophy $(\mathrm{LVH})$, a preclinical cardiac damage that in the long run may lead to potentially life-threatening

\footnotetext{
* Correspondence: esakgd@gmail.com

'Department of internal medicine, Jimma University, Jimma, Ethiopia

Full list of author information is available at the end of the article
}

complications $[2,3]$. LVH is strongly associated with major cardiovascular events [4-11]. Its echocardiographic prevalence varies from around $20 \%$ to over $70 \%$ based on the criteria used and population studied [4,7,12-14].

Cardiac hypertrophy is a compensatory response to cardiac insult of any cause [13]. It is the phenotypic consequence of interactions between genetic and non-genetic factors that involve multiple etiologies and complex mechanisms. Genes encoding proteins involved in the structure of the left ventricle (LV) and genes encoding cell signal transduction, hormones, growth factors, calcium homeostasis, 
and blood pressure are likely candidates for the development of LVH [15]. However, identification of specific genetic and molecular mechanisms for LVH in hypertensive patients is challenging [15-17]. For instance, CaMK4 gene deletion in mice was found to be linked with occurrence of hypertension, resultant LVH and reduced survival. However, treatment with furosemide in such mice prevented the development of both hypertension and LVH suggesting that $\mathrm{LVH}$ is a result of increased $\mathrm{BP}$ rather than being genetically determined [16].

Despite these challenges, the pathophysiologic mechanisms of LVH appear to be well established now. LVH is a myocardial remodeling [13] that ensues through activation of different signaling pathways [15] which involve mechanical [18] and neurohormonal activation by agents such as catecholamines and vasoactive peptides (angiotensin II or the endothelins) $[19,20]$. The benefits of beta-blockers and renin-angiotensin aldosterone system inhibitors in the treatment of CVDs are thus derived from their inhibition of these neurohormonal mechanisms [13]. Their importance in heart failure in particular has recently been elaborated [21].

Secondary messengers that regulate nuclear transcription factors activity (NF- $\kappa B, C R E B$, NFAT, and GATA-4) are activated in response to the neurohormonal activation. The nuclear transcription factors modify the expression of hypertrophic genes [22,23]. NF- $\mathrm{KB}$ is the most prominent of these transcription factors that modulate cellular response in myocardial remodeling [24]. This was shown by inhibition of NF-kB transcription activity by intracardiac injection of AdGRK5-NT that reduced LVH. Treatment with captopril (angiotensin converting enzyme inhibitor) also significantly reduces the heart size and inhibits NF- $\mathrm{kB}$ activity [25].

Though different mechanisms interplay in the development of $\mathrm{LVH}$, there is a consistent and independent interaction between hypertension and left ventricular mass (LVM) [3]. However, the relationship between degree of hypertension and LVM is not linear. LVH may occur in patients with borderline hypertension. It is a major risk factor for coronary artery disease all-cause mortality even in the absence of symptoms and other cardiovascular risk factors [26]. The effect is even more prominent in black patients [27] where it was found to be associated with greater relative and attributable risk than the traditional risk factors for coronary disease [28].

Apart from hypertension itself, different factors are believed to play a role in the development of LVH. Obesity, dyslipidemia, diabetes mellitus, smoking, old age and excessive alcohol intake are said to be positively correlated with the prevalence of LVH in hypertensive patients [12,29-32].

Studies regarding LVH and its sequel are scarce in Black Africans. Most prevalence data for hypertension and LVH as well as treatment recommendations are extrapolated from the findings in African Americans. The main aim of the current study is thus to assess the prevalence of left ventricular hypertrophy in Ethiopian hypertensive patients and role of ACE inhibitors in preventing $\mathrm{LVH}$ in patients with hypertension.

\section{Methods \\ Settings}

This is a cross-sectional study conducted at the Jimma University Specialized Hospital (JUSH) between May and August 2012. JUSH is a referral hospital for around 15 million people in southwest Ethiopia. It is one of the few teaching hospitals in the country. It is located in Jimma town, $356 \mathrm{~km}$ south-west of the capital Addis Ababa. At the time of the study, there were around 1100 patients on active follow-up for hypertension at hypertension clinic of the hospital. The clinic runs once a week every Wednesday. The service is rendered by internists, medical residents and medical interns.

\section{Selection of participants}

Hypertensive patients coming for follow-up to the hospital were consecutively recruited based on the selection criteria and their willingness to participate in the study. Over a period of four months, complete data from the patient interview, physical examination, chart review and echocardiographic assessment was done in 200 hypertensive patients.

\section{Inclusion criteria}

Any adult hypertensive patient over 18 years of age coming to the clinic for follow up was enrolled for the study based on their willingness and consent.

\section{Exclusion criteria}

All hypertensive patients with heart failure were excluded from the study.

\section{Data collection process and instrument}

The data were collected using a pre-tested structured questionnaire which was prepared specifically for this study. Patient interviews, BP and anthropometric measurements were done by nurses working in the clinic after one day of training. Chart review was done by medical residents. The questionnaire consisted of sociodemographic profiles; physical measurements (blood pressure, weight, height) and clinical records for comorbidities, duration of hypertension and the types of antihypertensive medications used. Blood pressure was measured with a sphygmomanometer. An average of three blood pressure measurements was taken to assess blood pressure control (the current and the last two visits). Height and weight were measured using a standard weighing scale and stadiometer respectively. 
These parameters were measured by patient standing straight without shoes and wearing only light clothes.

Transthoracic echocardiography was performed to measure parameters used to estimate left ventricular mass (LVM). M-mode tracing was done at the papillary muscle level of the left ventricle to measure posterior wall thickness in diastole (PWTd), interventricular septal wall thickness in diastole (IVSTd) and left ventricular internal diameter in diastole (LVIDd). Absolute LVM was calculated by the Devereux formula given as $0.8 * 1.04$ ((PWTd $\mathrm{cm}+$ IVSTd $\mathrm{cm}+$ LVIDd $\mathrm{cm})^{3}-$ LVIDd $\left.\left.^{3} \mathrm{~cm}\right)\right)+0.6$ grams [33]. The LVM was indexed to body surface area (BSA). LVH was defined as LVM/BSA of $>116 \mathrm{~g} / \mathrm{m}^{2}$ for men and $>96 \mathrm{~g} / \mathrm{m}^{2}$ for women [33].

\section{Data analysis}

Data were analyzed using SPSS version 20 . The findings were expressed as mean \pm standard deviation and/or percentages. Categorical variables were compared using Chi-square test and odds ratio with 95\% confidence interval. A P-value of less than 0.05 was considered statistically significant. The logistic regression model was done to identify predictors/risks of left ventricular hypertrophy.

\section{Ethical considerations}

Ethical clearance was obtained from Jimma university ethical review board. Informed written consent was obtained from every participant. The information collected from participants will remain confidential indefinitely. Patients with life threatening conditions were exempted from the study and were linked for appropriate care.

\section{Results}

\section{Background characteristics}

A total of 200 hypertensive patients were included in the study of which $57 \%$ were women. The mean age of the participants was $55.7 \pm 11.1$ years with a range of 22 to78 years. Hundred forty-nine (74.5\%) of them were older than 50 years. About $70 \%$ of them had hypertension for 10 years or more. The mean systolic blood pressure (SBP) and diastolic blood pressure (DBP) were $139.2 \pm 7.7 \mathrm{mmHg}$ and $89.2 \pm 5.7 \mathrm{mmHg}$ respectively (Table 1).

Thirty-nine (19.5\%) of patients have been diagnosed with diabetes and were on glucose lowering agents (insulin or oral glucose lowering agent), 28 of them had type 2 diabetes.

None of the participants reported smoking or use of alcohol.

The mean Body Mass Index (BMI) was $24.2 \pm 3.4 \mathrm{Kg} / \mathrm{m}^{2}$. Fifty-six (28\%) of them were found to be overweight and 14 patients $(7 \%)$ were classified as obese according to the standard classification of overweight as BMI $\geq 25 \mathrm{Kg} / \mathrm{m}^{2}$ and obesity as BMI $\geq 30 \mathrm{~kg} / \mathrm{m}^{2}$ (Table 1 ).
Table 1 Background Characteristics of hypertensive patients in Ethiopia

\begin{tabular}{|c|c|}
\hline Characteristics & \\
\hline Age (years), Mean $\pm S D$ & $55.7 \pm 11.1$ \\
\hline \multicolumn{2}{|l|}{ Age category, N (\%) } \\
\hline$<50$ & $51(25.5)$ \\
\hline$\geq 50$ & $149(74.5)$ \\
\hline \multicolumn{2}{|l|}{ Sex, N (\%) } \\
\hline Male & $86(43.0)$ \\
\hline Female & $114(57.0)$ \\
\hline \multicolumn{2}{|l|}{ Duration of hypertension, N (\%) } \\
\hline$<10 \mathrm{yrs}$ & $60(30.0)$ \\
\hline$\geq 10$ years & $140(70.0)$ \\
\hline \multicolumn{2}{|l|}{ History of diabetes } \\
\hline Yes & $39(19.5)$ \\
\hline No & $161(80.5)$ \\
\hline \multicolumn{2}{|l|}{ Blood pressure } \\
\hline $\mathrm{SBP}(\mathrm{mmHg})$, Mean $\pm \mathrm{SD}$ & $139.23 \pm 7.79$ \\
\hline $\mathrm{DBP}(\mathrm{mmHg})$, Mean $\pm \mathrm{SD}$ & $89.24 \pm 5.75$ \\
\hline $\mathrm{BMI}\left(\mathrm{Kg} / \mathrm{m}^{2}\right)$, Mean $\pm \mathrm{SD}$ & $24.22 \pm 3.47$ \\
\hline \multicolumn{2}{|l|}{ BMI $\left(\mathrm{Kg} / \mathrm{m}^{2}\right), N(\%)$} \\
\hline$<25$ & $130(65.0)$ \\
\hline $25-29$ & $56(28.0)$ \\
\hline$\geq 30$ & $14(7.0)$ \\
\hline
\end{tabular}

SBP - systolic blood pressure, DBP - diastolic blood pressure. $\mathrm{BMI}$ - Body mass index.

\section{Treatment of hypertension}

All of the participants were taking some types of antihypertensive agents at the time of the study. About $57 \%$ of them were taking a combination of two or more antihypertensive drugs. The most commonly used drug was hydrochlorothiazide used in 53\% of the participants as the only agent or in combination with others. About $42 \%$ of them were taking angiotensin converting enzyme (ACE) inhibitors alone or in combination with others. Beta-blocker (atenolol) alone or in combination with other agents was used by $38 \%$ of the participants. None of the patients were taking angiotensin receptor blockers (ARB) (Table 2).

\section{Echocardiographic findings and the Prevalence of left ventricular hypertrophy}

The mean posterior wall thickness in diastole (PWTd), interventricular septal wall thickness in diastole (IVSTd) and left ventricular internal diameter in diastole (LVIDd) were $1.28 \pm 0.25,1.38 \pm 0.31$ and $3.93 \pm 0.4$ centimeters respectively. The mean calculated left ventricular mass from the three parameters according to the Devereux formula was $193.4 \pm 60.6$ grams. When indexed to BSA, it was $107.3 \pm 33.6 \mathrm{~g} / \mathrm{m}^{2}$. 
Table 2 Types of anti-hypertensive drugs used by hypertensive patients in Ethiopia, August 2012

\begin{tabular}{lrr}
\hline Types of anti-hypertension drug & N & \% \\
\hline Thiazide diuretic only & 40 & 20.0 \\
ACE inhibitor only & 32 & 16.0 \\
Beta blocker only & 15 & 7.5 \\
ACE inhibitor + Thiazide diuretic & 18 & 9.0 \\
Beta blocker + Thiazide diuretic & 23 & 11.5 \\
Calcium channel blocker + Thiazide diuretic & 7 & 3.5 \\
ACE inhibitor + Beta blocker & 11 & 5.5 \\
ACE inhibitor + Calcium channel blocker & 4 & 2.0 \\
Calcium channel blocker + Beta blocker & 3 & 1.5 \\
Three drugs (different combinations) & 47 & 23.5 \\
\hline
\end{tabular}

The overall prevalence of left ventricular hypertrophy based on criteria of LMV/BSA $>116 \mathrm{~g} / \mathrm{m}^{2}$ for men and $>96 \mathrm{~g} / \mathrm{m}^{2}$ for women was $52 \%$. There was a significant difference in its prevalence between genders, $68.4 \%$ among women and $30.2 \%$ among men $(\mathrm{p}<0.001)$ (Table 3).

\section{Risk factors for the development of left ventricular hypertrophy \\ Age}

Of the 104 patients with left ventricular hypertrophy, 92 (88.4\%) were 50 years or older. A bivariate analysis showed that age $\geq 50$ years was associated with the development of LVH (crude OR: 5.24 95\% CI 2.53- 10.84, P < 0.001) (Table 3$)$. When age was adjusted for other variables in logistic regression, it remained an independent risk factor for the development of LVH (adjusted OR: 3.49, 95\% CI 1.33-9.14, $\mathrm{P}=0.011$ ) (Table 4).

\section{Gender}

The prevalence of $\mathrm{LVH}$ in women was found to be $68.4 \%$ versus $30.2 \%$ in men. Bivariate analysis showed that females were 5 times more likely to develop LVH as compared to their male counterparts (crude OR: 5.0, 95\% CI 2.72- 9.16, $\mathrm{P}<0.001$ ) (Table 3). Controlling for other potential risk factors on logistic regression, this effect remains significant (adjusted $\mathrm{OR}=7.69(3.23-20.0$ ), $\mathrm{P}<0.001$ ) (Table 4).

\section{BMI}

Overall, 70 (35\%) of the participants had BMI $\geq 25 \mathrm{Kg} / \mathrm{m}^{2}$. However, there was no significant difference in the proportion of LVH between individuals with normal or high BMI $(\mathrm{P}=0.172)$.

\section{Diabetes mellitus}

Diabetes was not found to be a significant predictor of LVH in this study. All of the 28 type 2 patients were
Table 3 Bivariate analysis of risk factors for Left ventricular Hypertrophy among hypertensive patients in Ethiopia

\begin{tabular}{|c|c|c|c|c|}
\hline \multirow[t]{2}{*}{ Predictor variables } & & \multicolumn{2}{|c|}{ LVH $(N=200)$} & \multirow[t]{2}{*}{ P-value } \\
\hline & & Yes, N (\%) & No, N (\%) & \\
\hline \multirow[t]{2}{*}{ Sex } & Female & $78(68.4)$ & $36(31.6)$ & $<0.001$ \\
\hline & Male & $26(30.2)$ & $60(69.8)$ & \\
\hline \multirow[t]{2}{*}{ Age } & $\geq 50$ years & $92(61.7)$ & $57(38.3)$ & $<0.001$ \\
\hline & $<50$ years & $12(23.5)$ & $39(76.5)$ & \\
\hline \multirow[t]{2}{*}{ BMI } & $\geq 25 \mathrm{Kg} / \mathrm{m}^{2}$ & $40(57.1)$ & $30(42.9)$ & 0.172 \\
\hline & $<25 \mathrm{Kg} / \mathrm{m}^{2}$ & $64(49.2)$ & $66(50.8)$ & \\
\hline \multirow[t]{2}{*}{ SBP } & $\geq 140 \mathrm{mmHg}$ & $65(63.7)$ & $37(36.3)$ & $<0.001$ \\
\hline & $<140 \mathrm{mmHg}$ & 39(39.8) & $59(60.2)$ & \\
\hline \multirow[t]{2}{*}{ DBP } & $\geq 90 \mathrm{mmHg}$ & $56(56.0)$ & $44(44.0)$ & 0.258 \\
\hline & $<90 \mathrm{mmHg}$ & $48(48.0)$ & $52(52.0)$ & \\
\hline \multirow[t]{2}{*}{ History of DM } & Yes & $20(51.3)$ & 19(48.7) & 0.920 \\
\hline & No & $84(52.2)$ & $77(47.8)$ & \\
\hline \multirow[t]{2}{*}{ Type of DM } & Type 2 & 15(53.6) & 13(46.4) & 0.897 \\
\hline & Type 1 & $5(45.5)$ & $6(54.5)$ & \\
\hline \multirow[t]{2}{*}{ ACE inhibitor } & No & $86(74.1)$ & $30(25.9)$ & $<0.001$ \\
\hline & Yes & 18(21.4) & $66(78.6)$ & \\
\hline \multirow[t]{2}{*}{ Beta Blocker } & Yes & $43(57.3)$ & $32(42.7)$ & 0.242 \\
\hline & No & $61(48.8)$ & $64(51.2)$ & \\
\hline \multirow[t]{2}{*}{ Duration of hypertension } & $\geq 10$ years & $88(62.9)$ & $52(37.1)$ & $<0.001$ \\
\hline & $<10$ years & $16(26.7)$ & $44(73.3)$ & \\
\hline \multirow[t]{2}{*}{ Thiazide diuretic } & Yes & $54(50.9)$ & $52(49.1)$ & 0.751 \\
\hline & No & $50(53.2)$ & $44(46.8)$ & \\
\hline \multirow[t]{2}{*}{ Calcium channel blocker } & Yes & $9(47.4)$ & $10(52.6)$ & 0.671 \\
\hline & No & $95(52.5)$ & $86(47.5)$ & \\
\hline
\end{tabular}

DM - diabetes mellitus, ACE - angiotensin converting enzyme.

taking oral glucose lowering agents as all type 1 patients were on insulin. However, neither the type of diabetes nor the treatment was associated with LVH.

\section{Degree of blood pressure control}

At the time of this study, about $60 \%$ of the participants had high blood pressure defined as $\mathrm{SBP} \geq 140 \mathrm{mmHg}$ and/or DBP $\geq 90 \mathrm{mmHg}$. Significant difference in prevalence of LVH was detected only when dichotomizing the

Table 4 Independent risk factors for Left ventricular Hypertrophy among hypertensive in Ethiopia

\begin{tabular}{lcccc}
\hline Risk factors & Adjusted OR & 95\% Cl for OR & P-value \\
\hline Age & 3.49 & 1.33 & 9.14 & 0.011 \\
Sex (female) & 7.69 & 3.23 & 20.0 & $<0.001$ \\
Systolic BP & 2.85 & 1.27 & 6.41 & 0.011 \\
ACE inhibitor & 0.08 & 0.03 & 0.19 & $<0.001$ \\
Duration of hypertension & 3.59 & 1.47 & 8.76 & 0.005 \\
\hline
\end{tabular}


high BP into SBP or DBP. Elevated systolic blood pressure was found to be an independent predictor of $\mathrm{LVH}$ in patients with hypertension, (adjusted OR: 2.85, 95\% CI $1.27-6.41, \mathrm{p}=0.011)$. However, a significant interaction between DBP and LVH was not seen $(\mathrm{p}=0.258)$ (Tables 3 and 4).

\section{Duration of hypertension}

About $70 \%$ of the participants reported that they had hypertension for 10 years or more. The prevalence of $\mathrm{LVH}$ in this group was $62.9 \%$ versus $26.7 \%$ in those who were less than 10 years since diagnoses. Adjusting for all potential risk factors, patients with longstanding hypertension ( $\geq 10$ years) were 3.59 times more likely to develop LVH as compared to those with less than 10 years of hypertension (adjusted OR: 3.59, 95\% CI 1.47- 8.76, $\mathrm{P}=0.005$ ) (Table 4).

\section{Types of antihypertensive agent used and the risk of $\mathrm{LVH}$}

Comparison of LVM index was done among each antihypertensive agent used. Apparently lower LVM was seen in patients taking ACE inhibitors alone or in combination with other agents at the time of the study. The findings were comparable among other antihypertensive agents. Multivariate logistic regression also showed a decreased risk of LVH (adjusted OR: 0.08, 95\% CI 0.03$0.19, \mathrm{p}<0.001$ ) for those on ACE inhibitors (Table 4).

ACE inhibitors were used more widely in patients older than 50 years (66.4\%) and in those with diabetes (82\%). These agents were used less often $(<50 \%)$ in other groups. The effect of ACE inhibitors on LVH was independent of these groupings. However, this effect vanished in those with high blood pressure (SBP $\geq 160$ ).

When we grouped antihypertensive agents to those with anti-remodeling effect (ACE inhibitors and betablockers) and non-anti-remodeling drugs (other groups), a positive trend towards anti-remodeling agents was seen though not statistically significant (adjusted OR: 0.11, 95\% CI 0.09-1.02, $\mathrm{p}<0.001$ ).

\section{Discussion}

Left ventricular hypertrophy, a preclinical cardiac damage, was found to be highly prevalent in Ethiopian hypertensive patients. Age, female gender, longstanding and systolic hypertension were found to be independent predictors for its occurrences. Use of ACE inhibitors was associated with decreased risk of LVH. This crosssectional study from a single health facility in Africa may give clues to the effect of ACE inhibitors in the treatment of hypertension and their effect on LVH in black patients.

$\mathrm{LVH}$ is an independent cardiovascular risk factor [3]. Its prevalence in hypertensive patients in most literatures worldwide varies from 20 to $70 \%$ based on the population studied and the criteria used [7,13,14,34]. The overall prevalence of left ventricular hypertrophy of $52 \%$ among hypertensive subjects in our study lies within this range.

Age was found to be an independent risk factor for LVH in most studies $[7,8,35,36]$. The finding in our study is also consistent with these findings.

Female gender was found to be an independent risk factor for LVH in hypertensive patients in our study with adjusted OR of 7.69. Different studies from around the world have shown that the gender effect on prevalence of LVH varies from population to population [35-39], whether ECG or echocardiography is used for its assessment [7] and criteria used [34]. A study in Pakistan, for instance, revealed that women were 11.35 times more likely to develop LVH than the male counterparts even after adjusting for other factors [37]. Similarly, studies in Nigeria [38], China [12] and the LIFE (losartan intervention for endpoint reduction in hypertension) study [39] showed a trend towards a higher prevalence in women. However, some studies from European countries have shown a higher prevalence in men $[35,36]$. Whether these differences are due to population studied or criteria used or cutoff points used need to be addressed in future studies.

The presences of diabetes [40] and high BMI [8,9] have shown significant correlations with LVH in most studies. However, in our study, neither history of diabetes nor the type of treatments for hyperglycemia showed any association with LVH. Our assessments for diabetes were based on only self-reported diagnosis without blood glucose test. Besides, the small sample size might not be enough to see this correlation. Absence of correlation between LVH and body habitus in our study can also be explained by the small sample size.

Uncontrolled systolic blood pressure $\geq 140 \mathrm{mmHg}$ was associated with the development of left ventricular hypertrophy in this study. However, no correlation was found between diastolic blood pressure and the occurrence of LVH. These findings are consistent with results from other studies [41]. The reason for this difference could be due to the fact that diastolic hypertension is associated more with diastolic dysfunction than systolic dysfunction and LVH [41].

Duration of hypertension was found to be an independent predictor of left ventricular hypertrophy in our study which is consistent with most studies from around the world $[42,43]$.

The fact that all of our study participants were nonsmokers and nonalcoholic was merely a chance occurrence. This can also be explained by the fact that the prevalence of smoking in Ethiopia is low, 3.3\% in the general population and $0.5 \%$ for women [44] who made for the larger part of our study participants. In addition, 
as most of our participants had a diagnosis of hypertension for over 10 years and all have been on treatment for their hypertension, abstinence from smoking for medical reason may also explain our findings.

As LVH is a cardiac remodeling problem [5,13], we tried to evaluate the effect of anti-remodeling drugs (beta-blockers and ACE inhibitors) on the risk of LVH. It was found that patients using $A C E$ inhibitors at the time of the study had a lower LVM index and decreased risk of LVH as compared to other agents. The effect of beta-blockers was however less pronounced. Evidences have shown that anti-remodeling agents like beta-blockers, ACE inhibitors and ARB have protective effect against development of LVH. Besides, they can even reverse an established LVH and improve left ventricular function [45-49]. We understand that such cross-sectional study like ours may not be enough to see the full effect of these drugs on regression of $\mathrm{LVH}$.

In addition to this, recent studies have also casted doubts on the benefits of these drugs among black patients [50]. Such evidences showed that ACE inhibitors, $\mathrm{ARB}$ and beta-blockers are less effective than calcium channel blockers and diuretics in black hypertensive patients with or without $\mathrm{LVH}$ due low plasma renin level in blacks [50,51]. However, most of these studies were extrapolated from findings in African-Americans. Multicenter studies in indigenous Africans would be ideal to identify best antihypertensive drug options in such setting where the dietary habits and physique are so diverse (for instance, West Africans versus East Africans).

Another explanation for the lack of effect of betablockers in our study may be due to the fact that most (56\%) of the patients on these agents had high SBP $(\geq 160 \mathrm{mmHg})$. In these patients, beta-blockers were used as additional antihypertensive agents after blood pressure control became difficult with original one or two types of antihypertensive drugs. It should also be reminded here that the benefit of beta-blockers on regression of LVH and uncomplicated hypertension is becoming questionable [52]. In addition to this, carvedilol is the beta-blocker of choice in patients with hypertensive LVH [53]. The beta-blocker used in our study was however atenolol.

The effect of ACE inhibitors on LVH also vanished in those with SBP $\geq 160 \mathrm{mmHg}$. This is contrary to the fact that ACE inhibitors induce left ventricular hypertrophy regression, independent of changes in blood pressure [54]. Cross-sectional study like ours may not be enough to see these effects.

Even though this study has come up with such important findings, there are important limitations worth mentioning here. First of all, the relatively small sample size might have contributed to the inability to detect the effect of certain risk factors for LVH. For example none of the participants reported a history of smoking or alcohol use. On the other hand, other potential risk factors for LVH like dyslipidemia, anemia and renal dysfunction were not assessed making an assessment of risk factors incomplete. Finally, as all of the participants were those on pharmacological treatment for hypertension, it may not be generalizable for all patients with hypertension in the country.

\section{Conclusion}

Left ventricular hypertrophy was found to be highly prevalent in Ethiopian hypertensive patients where BP control is suboptimal. Older age, female gender, longstanding and systolic hypertension were independent predictors of LVH. ACE inhibitor use on the other hand has been associated with lower risk of this complication. Taking these results and observations into consideration, we thus recommend early screening of hypertensive patients for LVH with either echocardiography or electrocardiography based on availability. Besides, we urge health care providers and policymakers to improve standards of care for hypertensive patients by optimizing BP control and working on those modifiable risk factors of LVH.

Last but not least, we recommend a large scale multicenter study to substantiate the findings in this research.

\section{Competing interests}

The authors declare that there is no conflict of interest associated with this research work.

\section{Authors' contributions}

GNJ designed the study, developed the instruments, supervised data collection, analyzed the data and wrote the manuscript. EKG participated in study design, instrument development, data analysis and writing of manuscript. WG participated in study design and instrument development, took part in data collection and editing manuscript. All authors read and approved the final manuscript.

\section{Acknowledgements}

The authors would like to acknowledge the study participants and Jimma University hospital for all the help provided during data collection. We would also like to thank Jimma University student research program for funding the study.

\section{Author details}

'Department of internal medicine, Jimma University, Jimma, Ethiopia.

${ }^{2}$ Department of radiology, Jimma University, Jimma, Ethiopia.

Received: 27 September 2013 Accepted: 15 January 2014 Published: 20 January 2014

\section{References}

1. Santulli G: Epidemiology of cardiovascular disease in the 21st century: updated numbers and updated facts. JCVD 2013, 1(1):1-2.

2. Schmieder RE: End organ damage in hypertension. Dtsch Arzteb/ Int 2010, 107(49):866-873.

3. Schillaci G, Verdecchia P, Porcellati C, Cuccurullo O, Cosco C, Perticone F: Continuous relation between left ventricular mass and cardiovascular risk in essential hypertension. Hypertension 2000, 35:580-586.

4. Levy D, Garrison RJ, Savage DD, Kannel WB, Castelli WP: Prognostic implications of echocardiographically determined Left ventricular mass in the Framingham Heart Study. N Engl J Med 1990, 322:1561-1566. 
5. Artham SM, Lavie CJ, Milani RV, Patel DA, Verma A, Ventura HO: Clinical impact of left ventricular hypertrophy and implications for regression. Prog Cardiovasc Dis 2009, 52(2):153-167.

6. Bombelli M, Facchetti R, Carugo S, Madotto F, Arenare F, Quarti-Trevano F, et al: Left ventricular hypertrophy increases cardiovascular risk independently of in-office and out-of office blood pressure values. J Hypertens 2009, 27(12):2458-2564.

7. Ruilope LM, Schmieder RE: Left ventricular hypertrophy and clinical outcomes in hypertensive patients. Am J Hypertens 2008, 21(5):500-508.

8. Larsen CT, Dahlin J, Blackburn H, Scharling H, Appleyard M, Sigurd B: Prevalence and prognosis of electrocardiographic left ventricular hypertrophy, ST segment depression and negative T-wave; the Copenhagen City Heart Study. Eur Heart J 2002, 23(4):315-324.

9. Lonn E, Mathew J, Pogue J, Johnstone D, Danisa K, Bosch J, et al: Relationship of electrocardiographic left ventricular hypertrophy to mortality and cardiovascular morbidity in high risk patients. Eur $J$ Cardiovasc Prev Rehabil 2003, 10(6):420-428.

10. Koren MJ, Devereux RB, Casale PN, Savage DD, Laragh JH: Relation of left ventricular mass and geometry to morbidity and mortality in uncomplicated essential hypertension. Ann Intern Med 1991, 114(5):345-352.

11. Cipriano C, Gosse P, Bemurat L, Mas D, Lemetayer P, N'Tela G, Clementy J: Prognostic value of left ventricular mass and its evolution during treatment in the Bordeaux cohort of hypertensive patients. Am J Hypertens 2001, 14(6pt 1):524-529.

12. Wang SX, Xue H, Zou YB, Sun K, Fu CY, Wang H, Hui RT: Prevalence and risk factors for left ventricular hypertrophy and left ventricular geometric abnormality in the patients with hypertension among Han Chinese. Chin Med J (Engl) 2012, 125(1):21-26.

13. Knoll R, laccarino G, Tarone G, Hilfiker-Kleiner D, Bauersachs J, Leite-Moreira AD, et al: Towards a re-definition of 'cardiac hypertrophy' through a rational characterization of left ventricular phenotypes: a position paper of the Working Group 'Myocardial Function' of the ESC. Eur J Heart Fail 2011, 13:811-819.

14. Adebiyi AA, Ogah OS, Aje A, Ojji DB, Adebayo AK, Oladapo OO, et al: Echocardiographic partition values and prevalence of left ventricular hypertrophy in hypertensive Nigerians. BMC Med Imaging 2006, 6(10):183-188.

15. Marian AJ: Genetic determinants of cardiac hypertrophy. Curr Opin Cardiol 2008, 23(3):199-205.

16. Santulli G, Cipolletta E, Sorriento D, Del Giudice C, Anastasio A, Monaco S, et al: CaMK4 Gene deletion induces hypertension. J Am Heart Assoc 2012, 1:4.

17. Santulli G, Trimarco B, laccarino G: GRK2 and hypertension: molecular insights and pathophysiological mechanisms. High Blood Press Cardiovasc Prev 2013, 20(1):5-12.

18. Oparil S: Pathogenesis of ventricular hypertrophy. J Am Coll Cardiol 1985, 5(6 Suppl):57B-65B.

19. Blaufarb IS, Sonnenblick EH: The renin-angiotensin system in left ventricular remodeling. Am J Cardiol 1996, 77:8C-16C.

20. Brunner F, Bras-Silva C, Cerdeira AS, Leite-Moreira AF: Cardiovascular endothelins: essential regulators of cardiovascular homeostasis. Pharmacol Ther 2006, 111:508-531.

21. Santulli G: Adrenal signaling in heart failure: something more than a distant ship's smoke on the horizon. Hypertension 2014, 63(2):215-216.

22. De Windt LJ, Lim HW, Bueno OF, Liang Q, Delling U, Braz JC, et al: Targeted inhibition of calcineurin attenuates cardiac hypertrophy in vivo. Proc Natl Acad Sci U S A 2001, 98:3322-27.

23. Liang $\mathrm{Q}$, Molkentin JD: Divergent signaling pathways converge on gata4 to regulate cardiac hypertrophic gene expression. J Mol Cell Cardiol 2002, 34:611-16.

24. Gupta S, Young D, Sen S: Inhibition of NF-kB induces regression of cardiac hypertrophy, independent of blood pressure control, in sponta-neously hypertensive rats. Am J Physiol Heart Circ Physiol 2005, 289:H20-H29.

25. Sorriento D, Santulli G, Fusco A, Anastasio A, Trimarco B, laccarino G: Intracardiac injection of AdGRK5-NT reduces left ventricular hypertrophy by inhibiting NF-kappaB-dependent hypertrophic gene expression. Hypertension 2010, 56(4):696-704.

26. Chamber J: Left ventricular hypertrophy. BMJ 1995, 311:273-4.

27. Okin PM, Kjeldsen SE, Dahlöf B, Devereux RB: Racial differences in incident heart failure during antihypertensive therapy. Circ Cardiovasc Qual Outcomes 2011, 4:157-164.

28. Liao Y, Cooper RS, McGee DL, Mensah GA, Ghali JK: The relative effects of left ventricular hypertrophy, coronary artery disease, and ventricular dysfunction on survival among black adults. JAMA 1995, 273(20):1592-7.
29. Cuspidi C, Negri F, Muiesan ML, et al: Prevalence and severity of echocardiographic left ventricular hypertrophy in hypertensive patients in clinical practice. Blood Press 2010, 20:3-9.

30. De Simone G, Devereux RB, Roman MJ, Alderman MH, Laragh JH: Relation of obesity and gender to left ventricular hypertrophy in normotensive and hypertensive adults. Hypertension 1994, 23(5):600-6.

31. Sundström J, Lind L, Vessby B, Andrén B, Aro A, Lithell H: Dyslipidemia and an unfavourable fatty acid profile predict left ventricular Hypertrophy 20 years later. Circulation 2001, 103(6):836-41.

32. Manolio TA, Levy D, Garrison RJ, Castelli WP, Kannel WB: Relation of alcohol intake to left ventricular mass: The Framingham heart study. J Am Coll Cardiol 1991, 17(3):717-21.

33. Lang RM, Bierig M, Devereux RB, Flachskampf FA, Foster E, Pellikka PA, et al: Recommendations for chamber quantification: A report from the American Society of Echocardiography's Guidelines and Chamber Quantification Writing Group, developed in conjunction with the European Association of Echocardiography, a branch of the European Society of Cardiology. J Am Soc Echocardiogr 2005, 18(12):1440-63.

34. Coca A, Gabriel R, de la Figuera M, Lopez-Sendon JL, Fernandez R, Sagastagoitia JD, et al: The impact of different echocardiographic diagnostic criteria on the prevalence of left ventricular hypertrophy in essential hypertension: The VITAE study. J Hypertens 1999, 17(10):1471-80.

35. Lozano JV, Redón J, Cea-Calvo L, Fernández-Pérez C, Navarro J, Bonet A González-Esteban J: Left ventricular hypertrophy in the Spanish hypertensive population:the ERIC-HTA study. Rev Esp Cardiol 2006, 59(2):136-42.

36. Kaspruk G, Mitchenko O, Romanov V: Left ventricular hypertrophy and cardiovascular risk factors at patients with arterial hypertension and metabolic syndrome. J Hypertens 2012, 30:e61-e62.

37. Jafary FH, Jafar TH: Disproportionately high risk of left ventricular hypertrophy in Indo-Asian women: a call for more studies. Echocardiography 2008, 25:812-19.

38. Adekunle AE, Adeseye Al, Adebayo OT, Olatayo AA, Joseph OO, Ayodele AR: Left ventricular mass formulae and prevalence rates of echocardiographic left ventricular hypertrophy in Nigerians with essential hypertension. N Am J Med Sci 2013, 5(5):325-9.

39. Gerdts E, Okin PM, De Simone G, Cramariuc D, Wachtell K, Boman K, Devereux RB: Gender differences in left ventricular structure and function during antihypertensive treatment: the Losartan Intervention for Endpoint Reduction in Hypertension Study. Hypertension 2008, 51:1109-1114.

40. Palmieri V, Bella JN, Arnet DK, Liu JE, Oberman A, Schuck MY, et al: Effect of type 2 diabetes mellitus on left ventricular geometry and systolic function in hypertensive subjects: Hypertension Genetic Epidemiology Network (HyperGEN) study. Circulation 2001, 103(1):102-7.

41. Ito O, Okamoto M, Murakami Y, Nakayama R: Correlations between blood pressure, left ventricular hypertrophy, and left ventricular diastolic function in hypertensive patients. J Cardiol 1991, 21(4):931-41.

42. Nardi E, Palermo A, Mulè G, Cusimano P, Cerasola G, Rini GB: Prevalence and predictors of left ventricular hypertrophy in patients with hypertension and normal electrocardiogram. Eur J Prev Cardiol 2013, 20(5):854-61.

43. Koziolova NA, Shatunova IM, Lazarev IA: Risk factors of development of left ventricular hypertrophy in patients with hypertensive disease with high compliance to treatment. Kardiologiia 2012, 52(4):25-30.

44. World Health organization: WHO Report on the Global Tobacco Epidemic. Country profile: Ethiopia; 2011. http://www.who.int/tobacco/surveillance/ policy/country_profile/eth.pdf.

45. Almazov VA, Shlyakhto EV, Konrady AO, Macsimova TA, Zaharov DV Rudomanov OG: Correlation of hypertensive cardiac remodelling: comparison of different antihypertensive therapies. Med Sci Monit 2000 6(2):309-13.

46. Gosse P, Roudaut R, Herrero G, Dallocchio M: Beta-blockers vs. angiotensin-converting enzyme inhibitors in hypertension: effects on left ventricular hypertrophy. J Cardiovasc Pharmacol 1990, 16(5):S145-50.

47. Trimarco B, Ricciardelli B, De Luca N, Cuocolo A, Volpe M, Lembo G, Condorelli M: Reversal of left ventricular hypertrophy following treatment with beta-blockers: experience with tertatolol. Am J Nephrol 1986, 6(Suppl 2):94-9.

48. George T, Ajit MS, Abraham G: Beta blockers \& left ventricular hypertrophy regression. Indian Heart J 2010, 62(2):139-42.

49. Cuspidi C, Negri F, Zanchetti A: Angiotensin II receptor blockers and cardiovascular protection: focus on left ventricular hypertrophy 
regression and atrial fibrillation prevention. Vasc Health Risk Manag 2008, 4(1):67-73.

50. Julius S, Alderman MH, Beevers G, Dahlöf B, Devereux RB, Douglas JG, et al: Cardiovascular risk reduction in hypertensive black patients with left ventricular hypertrophy: the LIFE study. J Am Coll Cardiol 2004, 43(6): 1047-55.

51. Gibbs CR, Beevers DG, Lip GY: The management of hypertensive disease in black patients. QJM 1999, 92(4):187-92

52. Bangalore S, Messerli FH, Kostis JB, Pepine CJ: Cardiovascular protection using beta-blockers. J Am Coll Cardiol 2007, 50(7):563-572.

53. Katholi RE, Couri DM: Left ventricular hypertrophy: major risk factor in patients with hypertension: update and practical clinical applications. Int J Hypertens 2011, 2011:495349.

54. Lièvre M, Guéret P, Gayet C, Roudaut R, Haugh MC, Delair S, Boissel JP: Ramipril-induced regression of left ventricular hypertrophy in treated hypertensive individuals. HYCAR Study Group. Hypertension 1995, 25(1):92-7.

doi:10.1186/1756-0500-7-45

Cite this article as: Jaleta et al:: Left ventricular hypertrophy among black hypertensive patients: focusing on the efficacy of angiotensin converting enzyme inhibitors. BMC Research Notes 2014 7:45.

\section{Submit your next manuscript to BioMed Central and take full advantage of:}

- Convenient online submission

- Thorough peer review

- No space constraints or color figure charges

- Immediate publication on acceptance

- Inclusion in PubMed, CAS, Scopus and Google Scholar

- Research which is freely available for redistribution 